\title{
TWO-DECADE RETROSPECTIVE OF GERMAN-RUSSIAN COOPERATION IN THE FIELD OF SAFE RADIOACTIVE WASTE MANAGEMENT
}

\author{
Petrov V. A. ${ }^{1}$, Krone Jü. ${ }^{2}$, Kamnev E. N. ${ }^{3}$, Timayer T. ${ }^{4}$ \\ ${ }^{1}$ Federal State Budgetary Institution of Science Institute of Geology of Ore Deposits, Petrography, \\ Mineralogy and Geochemistry of the Russian Academy of Sciences, Moscow, Russia \\ ${ }^{2}$ BGE TECHNOLOGY GmbH, Peine, Germany \\ ${ }^{3}$ JSC Leading Design and Survey and Research Institute of Industrial Technology, Moscow, Russia \\ ${ }^{4}$ Federal Office for Geosciences and Natural Resources (BGR), Hannover, Germany
}

Article received on June 5, 2021

This paper briefly overviews a two-decade retrospective of a fruitful cooperation between German and Russian departments and experts in such a sensitive, high-tech and science-intensive area as radioactive waste disposal. The paper indicates the kea areas of this cooperation, as well as the most important results achieved.

Keywords: radioactive waste, long-term safety demonstration, radioactive waste storage facilities and repositories, underground research laboratory, deep disposal facility for radioactive waste.

\section{Introduction}

Constructive scientific and technical GermanRussian cooperation in the field of radioactive waste (RW) management started in 2001, when, the areas for further cooperation between specialists of both countries in various field of earth sciences were consolidated under an intergovernmental agreement between the State Corporation Rosatom and the German Federal Ministry of Economy and Technology (BMWi). Until that time, cooperation between Russian and German scientists mainly addressed the topic of reactor safety.

An additional impetus to the scientific and technical cooperation of both countries on the research in the field of reactor safety and RW disposal was given by a decisions of the $2^{\text {nd }}$ joint coordination expert group meeting held in Berlin on June 10-11, 2003, which provided for the continuation of joint efforts on several topics launched in 2001.

Since then, joint workshops of German and Russian specialists have been held annually. These workshops were primary held to coordinate common efforts on the safety of long-term RW disposal and on the optimization of conceptual high-level waste (HLW) disposal designs. These collective efforts featured a number of German experts, namely, those from BGE TECHNOLOGY (BGETec) $\mathrm{GmbH}$ (formerly DBE TECHNOLOGY $\mathrm{GmbH}$ ) and Gesellschaft für Anlagenund Reaktorsicherheit (GRS) $\mathrm{mbH}$, as well as experts from universities and institutes in Frankfurt am Main 
and Karlsruhe. A bit later, the Federal Office for Geosciences and Natural Resources (BGR, Bundesanstalt für Geowissenschaften und Rohstoffe) also joined the work.

\section{A brief overview of the joint efforts and their results}

In accordance with the priorities put forward by Minatom, the first stages of research were primarily explored the opportunities for safe final RW disposal in permafrost rocks on the Novaya Zemlya archipelago. A consortium of European experts headed by DBE TECHNOLOGY GmbH and working in close cooperation with JSC VNIPIpromtechnologii, confirmed the fundamental feasibility of such an original concept for short-lived RW [1]. Then the studies were extended to explore the opportunities for the final isolation of HLW in deep crystalline rocks, in particular, on the territory of PA Mayak (Chelyabinsk region), in the vicinity of the Mining and Chemical Combine (MCC, Krasnoyarsk Territory) and later investigated were the clay formations in the Leningrad region (Sosnovy Bor).

Most careful attention during these joint efforts was paid to the long-term safety demonstration of RW storage facilities and repositories. In this context, a special role was assigned to the establishment of an underground research laboratory (URL) in the MCC area at the Yeniseiskiy site constituting to the Nizhnekanskiy granite massif assuming further possible URL upgrading to a deep disposal facility for radioactive waste (DDFRW).

VNIPIpromtechnologii has been engaged in this research for fifteen years under a special contract signed with DBE TECHNOLOGY GmbH regularly providing the German side with initial data on the material composition of granitoids in the Nizhnekanskiy massif, sorption properties of the rocks at the Yeniseiskiy site, groundwater migration, the stress-strain state of the massif (jointly with the Geophysical Center of the Russian Academy of Sciences) to assess the long-term safety of RW disposal [2]. DBE TECHNOLOGY GmbH, GRS and BGR processed these data using purposely developed software. While maintaining constant cooperation with the Russian side, at regular bilateral meetings, these organizations discussed the results obtained and outlined the areas requiring further research.

At the last stages of the aforementioned agreement, the transport flowchart for the RW containers transportation and their emplacement into the mine shaft was discussed, as well as the design options that would allow to equip the URL with purposely designed research installations [3].
The results of these joint efforts were discussed in a number of reports (projects) of the German side.

Based on the initial data obtained by Russian experts, a number of projects has been implemented in Germany, namely: ASTER (2001-2005) [4], WIBASTA (2005-2008) [5], URSEL (2009-2015) [6], SUSE (2016-2019), SUSE PLUS (2020-2023). Each of these projects resulted in a report titled similarly to the name of the relevant project and summarizing its R\&D findings.

For example, the ASTER project (Requirements for the Exploration of an HLW Disposal Site in Hard Rocks) considers the findings of the below two projects based on data previously obtained by Russian specialists during their research focused on potential RW disposal sites:

B2 - Research on the final disposal of highly radioactive waste in deep granite formations (area of the Mining and Chemical Combine, Zheleznogorsk, Krasnoyarsk Territory);

B3 - Research on the final disposal of highly radioactive and heat-generating vitrified waste in deep porphyritic formations (the area of the Production Association Mayak, Ozersk, Chelyabinsk region).

The goal of the ASTER project was to develop some methodological recommendations for a wellfounded exploration program and siting recommendations for HLW repository in Russia based on the example of the MCC and PA Mayak territories allowing to ensure the most important aspects associated with the long-term final disposal safety. However, such a problem setup involves a very specific aspect: already early in the site exploration and disposal planning, actual geological scientific information is required for the safety assessment and this information can be obtained only from further site research. Thus, unlike common practice, it was supposed to carry out more extensive and at the same time more costly operations focused on the comprehensive characterization of potential disposal sites. On the Russian side, the head organization was JSC VNIPIpromtechnologii that engaged the specialists from IGEM RAS, Radium Institute named after V. G. Khlopin, VNIPIET, KNIIGiMS, PA Mayak, MCC, FSBSI GC RAS [7].

On the German side, the work was coordinated by BGR with the involvement of specialists from DBE TECHNOLOGY GmbH, GRS and the Karlsruhe Institute of Technology (KIT, formerly the Karlsruhe Research Center). Thus, based on the presented geological-geomorphological and geological-geophysical data, one of the first geological 3D models of a potential disposal site was developed by BGR for the Kamenniy site in the MCC area using the openGEO software (Figure 1). 


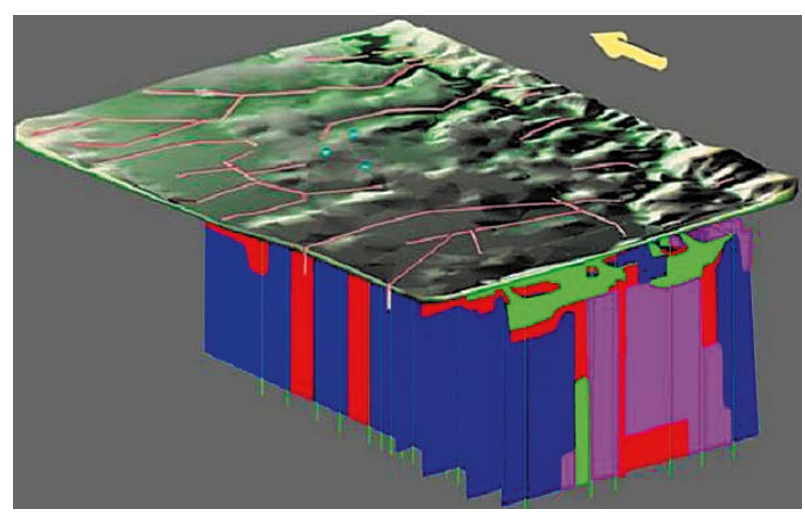

Figure 1. Rock permeability model for the Kamenniy site (Nizhnekanskiy granite massif). The surface topography is shown and blocks with high (green and purple) and low (red and blue) permeability are highlighted. Arrow points north

To deepen the knowledge on the prospects of final HLW disposal in granites in 2005, a delegation of BGR specialists involving DSc Otto Bornemann, Jorg Hammer and Michael Einhorn visited the site of PJSC Priargunsky Industrial Mining and Chemical Association (PJSC PIMCU) in Eastern Transbaikalia (Krasnokamensk). As was agreed with the management of the Combine, deep horizons of the Antey deposit constituting to the granites of ore-hosting Streltsovskaya caldera basement and the Tulukuevskoe deposit located within volcanic rocks were selected for further study. At both sites, uranium migration, accumulation and redistribution in oxidizing (Tulukuevsky quarry) and reducing (lower horizons of the Antey deposit) conditions were studied for many years by IGEM RAS under a research focused on the uranium deposits considered as natural analogues of RW disposal facilities $[8,9]$. In addition, deep horizons of the Antey deposit were selected due to the intense manifestation of rock bumps which could affect the safety of the underground infrastructure.

Structural-geological, petrographic-mineralogical and structural-petrophysical mapping results formed a basis for a 3D geological model of the field's lower part (Figure 2). It integrates the infrastructure of mine excavations, the planes of the main faults and the metasomatite blocks, which differ in their composition, properties and structural control.

The model developed involved some digitized horizontal plans and sections (1:500) provided by PJSC PIMCU's geological survey service. For modeling purposes, the openGeo software package was used to process the entire dataset based on linear wireframe development method that connected point data to each other assuming further triangulation within this frame. The model is built in a

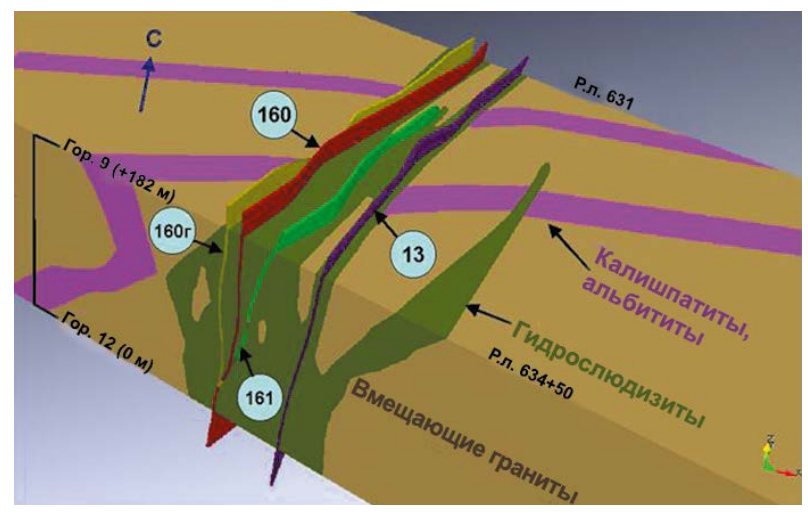

Figure 2. Simplified 3D model showing the lower part of the Antey field developed based on the openGeo software package. The vein-like bodies of Paleozoic K-feldspar and albitites associated with prototectonic elements are cut by faults 13, 160, 161 and $160 \mathrm{~g}$ showing the spread of Mesozoic hydromica, ore bodies, ore-accompanying and post-ore alterations. Arrow points north

real coordinate system, and the distances in it correspond to the true ones. The use of the openGeo software later allowed to:

- identify the exact position and volumes of geological bodies and structures in any (vertical or horizontal) section;

- to specify the epicenters of rock pressure manifestation (impacts, falls, peeling of rocks);

- correct and supplement the developed "core" of the model with any newly received information (geological, geophysical, mine surveying, mineralogical, petrophysical, geomechanical, etc.).

It should be noted that the developed 3D model has also largely contributed to some new insights on the nature of structural mineralization control in the field [10].

Extremely important were the findings on the migration behavior and concentration of uranium (radionuclides) in the aeration zone of the Tulukuevskoye deposit, including the factors affecting the dynamics of the modern oxidation front advancement, the most important of which is the presence of intrafault physical and chemical reaction barriers. They trap U(VI) effectively and convert it into insoluble U (IV) form due to the reactivity of Fe-Mn-oxyhydroxides, impregnated carbonaceous matter and microbial products - ferrihydrites [11].

The WIBASTA project (Performance Investigation of Engineered and Geologic Barriers of a HLW Repository in Magmatic Host Rocks) involved some research on the geological barriers at the Yeniseiskiy site (Nizhnekansky granite massif in the MCC area) to investigate its structure and retardation properties, to compile a list of missing data and identify the uncertainties in the predictions, as well as to develop some recommendations concerning 
further research. The project addressed the following key tasks:

- features of the geological structure were identified with some structural-tectonic site zoning performed to identify weakly disturbed blocks of crystalline rocks within its boundaries that could be considered favorable for underground RW disposal;

- the composition and heterogeneity of the geological barrier's internal structure was studied;

- the barrier properties of the host rocks were evaluated to demonstrate the long-term safety of underground RW disposal.

The following main conclusions were drawn based on this study:

- data on the geological structure and petrographic composition of metamorphic rock strata, in particular when it comes to great depths, as well as the data on the network of faults should be considered insufficient, which would affect the repository design concept;

- data on the geomechanical and thermophysical properties of rocks were considered insufficient, although IGEM RAS and DBE TECHNOLOGY GmbH have provided some additional new materials;

- data on the hydrogeology of a potential repository site were considered insufficient;

- data on the sorption properties of rocks, in particular, on spessartites with low thermal conductivity, developed, for example, in the Verkhne-Itatsky area were considered insufficient;

- poorly studied were the issues associated with the development of long-term geological forecasts, including relevant aspects associated with erosion, tectonic and seismic processes, possible glaciation, etc. It was proposed to take into account the German experience in the geological exploration implemented under the RW and SNF repository siting efforts;

- a facility being considered so important from the national perspective requires certain level of openness (the population should have access to the research results);

- experts will have to check the results and the conclusions (therefore, a system should be put in place to ensure the high quality of efforts taken to provide the core storage until the end of the repository licensing process);

- strict adherence to applicable standards and norms is required, including those associated with the core material sampling, identification of groundwater chemical composition, geochemical analyzes, etc.

The URSEL project was focused on the sustainability of HLW disposal systems sited in crystalline rock formations (Grimzel, Aspo, ONKALO), namely in terms of their safety, based on a comprehensive analysis of URL experiments. Particular attention was paid to the models presenting groundwater flows and radionuclide transport developed based on geological and hydrogeological data from Russian partner organizations. As part of the project, specialists from GRS, BGR and the St. Petersburg branch of IGE RAS (V. G. Rumynin's working group) have evaluated the main characteristics of a geological barrier constituting to a potential Yeniseiskiy site repository. The codes $\mathrm{d} 3 \mathrm{f}$ and $\mathrm{r} 3 \mathrm{t}$ were used to build a 2D vertical model of the fractured-porous medium in the investigated area. The RepoTEND code was used to estimate the advective transport of radionuclides through a fractured medium accounting for diffusion into the rock matrix in its one-dimensional implementation. Sorption $\mathrm{dy}-$ namics in cracks with different mineral content was evaluated and a preliminary closure concept for a HLW repository planned to be constructed at the Yeniseiskiy site was proposed.

In parallel with the research focused on granitoid rocks, clayey host rocks were investigated under the Analytical Research on the Safety of a Radioactive Waste Storage Facility Sited in a Diagenetically Modified Clay Formation at the Post-Operation Stage (SAnToS) [12]. The project was based on actual data from the geological exploration of the Kotlinsky clays in the Leningrad region (Sosnovy Bor) provided by the St. Petersburg branch of IGE RAS. It was supplemented by German know-how on clay formations obtained, in particular, in underground laboratories Mol (Belgium), Mont-Terri (Switzerland) and Meuse-Haute Marne (France).

Further technical support of Russian research and scientific and technical cooperation in the field of final HLW disposal was provided under the SUSE research project (Analytical Studies on the Safety of Final Disposal Systems in Crystalline Rocks). At the same time, EBS stability was thoroughly evaluated based on crystalline rock categorization methods that allowed to evaluate rock suitability using the experience gained during the implementation of other projects on RW storage facilities. It was shown that information on the parameters of hydraulically active fracture systems was essential for the construction of detailed geostructural-hydrogeological models of HLW disposal sites. To improve the database, additional experimental data on the host rock composition and properties were collected. Increased level of detail in the geostructural modelling provided a basis for realistic forecasts of groundwater flows and radionuclide distribution. SUSE PLUS is considered as a continuation of the SUSE project that elaborated on the topics addressed in the latter one. Under a five-sided 
agreement signed by two Russian (FSUE NO RAO and IBRAE RAS) and three German (BGE TECHNOLOGY $\mathrm{GmbH}$, GRS and BGR) organizations on September 5, 2019 at the 10th joint coordination meeting, relevant areas of focus were specified. These areas mainly corresponded to the topics of the SUSE PLUS project on which joint research is still underway:

- characteristics of fault-fracture systems;

- improvement of the 3D geostructural-hydrogeological rock mass model that would allow to visualize the main faults;

- collection of additional data on rock composition and properties (to supplement the already available data [13]);

- development of regional 3D filtration and transport models;

- mastering the methods proposed for R\&D planning in the underground laboratory.

\section{Conclusion}

Since 2001, a wide range of joint research has been performed in numerous areas and addressing various fields of knowledge to substantiate the long-term safety of RW storage facilities and repositories sited in various geological formations. All the approaches developed and the results obtained were discussed at numerous working meetings and scientific and methodological workshops. Specialists from the following Russian organizations took part in the meetings: State Corporation Rosatom, FSUE NO RAO, STC NRS, JSC VNIPIpromtechnologii, JSC SPII VNIPIET, FSUE MCC, JSC SCC, FSUE PA Mayak, FSUE VNIIEF, JSC SSC RIAR, JSC NIKIET, SRC Kurchatov Institute, Radium Institute named after V. G. Khlopin, JSC Atomenergoproekt, FSBI Gidrospetsgeologiya, Nuclear Safety Institute of the Russian Academy of Sciences, IGEM RAS, IGE RAS, GC RAS, Frumkin Institute of Physical Chemistry and Electrochemistry Russian Academy of Sciences (IPCE RAS), NRNU MEPhI, Moscow State University MGU, Tomsk Polytechnic University, etc. According to most conservative estimates, a total of over 70 joint scientific papers (articles in journals, abstracts in conference proceedings, chapters in monographs, etc.) have been published [14].

Several times, technical tours were also arranged for Russian specialists to RW management facilities available in the Federal Republic of Germany, for example: Gorleben, Asse, Morsleben and Konrad.

The experience of the past decades clearly demonstrates the need for continued promotion of scientific and technical cooperation between Russian and German specialists to address the problems faced by both countries in the field of RW management.

\section{References}

1. Lindberg C., Krone J., Christensen G., Engelhardt H. J., Filbert W., Munz A., Skagius K., Torstenfelt B., Ziegenhagen J. Second Phase of the Assessment of the Repository at Novaya Zemlya. Final Report. DBE TECHNOLOGY GmbH, December, 2003.

2. Anderson E. B., Belov S. V., Kamnev E. N. et al. Podzemnaya izolyatsiya radioaktivnykh otkhodov [Underground Isolation of Radioactive Waste]. Edited by V. N. Morozov. Moscow, "Gornaya kniga” Publ., 2011. $592 \mathrm{p}$.

3. Kamnev E. N., Morozov V. N., Tatarinov V. N., Kaftan V. I. Geodynamic aspects of investigations in underground research laboratory (Nizhnekansk Massif). Eurasian Mining, 2018, no. 2, pp. 11-14.

4. Wallner M., Mrugalla S., Hammer J., Brewitz W., Fahrenholz Ch., Fein E., Filbert W., Haverkamp B., Jobmann M., Krone J., Lerch Ch., Ward P., Weiß E., Ziegenhagen J., Gupalo T., Kamnev E., Konovalov V., Lopatin V., Milovidov V., Prokopova O. Anforderungen an die Standorterkundung für Haw-Endlager im Hartgestein (ASTER). Abschlussbericht. Peine, DBE TECHNOLOGY GmbH, 2005.

5. Jobmann M., Brewitz W., Fahrenholz Ch., Fein E., Hammer J., Keesmann S., Krone J., Mrugalla S., Wolf J., Ziegenhagen J. Untersuchungen zur Wirksamkeit des geologischen und geotechnischen Barrierensystems im Hinblick auf die Standortauswahl in magmatischen Gesteinen (WIBASTA). Peine, DBE TECHNOLOGY GmbH, 2008.

6. Jobmann M., Flügge J., Hammer J., Herold P., Krone J., Kühnlenz T., Li H., Lommerzheim A., Meleshyn A., Wolf J. Site-specific evaluation of safety issues for high-level waste disposal in crystalline rocks. Final Report. Peine, DBE TECHNOLOGY GmbH, 2015. 7. Tatarinov V., Kaftan V., Morozov V., Kamnev E., Tatarinova T. Reduction of the geodynamic risk in the disposal of radioactive waste in geological formations. 18 International multidisciplinary conference, SGEM 2018. Section Nuclear Technologies, Vienna, 2018. Vol. 18, issue 4.3, pp.11-21.

8. Laverov N. P., Petrov V. A., Poluektov V. V., Nasimov R. M., Hammer J., Burmistrov A. A., Shchukin S. I. Uranovoye mestorozhdeniye Antey prirodnyy analog khranilishcha OYAT i podzemnaya geodinamicheskaya laboratoriya $\mathrm{v}$ granitakh [The Antey uranium deposit as a natural analogue of an SNF Repository and an underground geodynamic laboratory in granites]. Geologiya rudnykh mestorozhdeniy - Geology of Ore Deposits, 2008, vol. 50, no. 5, pp. 387-413.

9. Petrov V. A., Poluektov V. V., Hammer J., Schukin S. I. Uranium mineralization in fractured welded tuffs of the Krasnokamensk Area: transfer from ancient to modern oxidizing conditions. In: The New 
Uranium Mining Boom: Challenge and lessons learned. B. J. Merkel, M. Schipek (edit.). Springer-Verlag Berlin Heidelberg, 2011. Pp. 701-710.

10. Petrov V. A., Rebetsky Yu. L., Poluektov V. V., Burmistrov A. A. Tektonofizika gidrotermal'nogo rudoobrazovaniya: primer molibden-uranovogo mestorozhdeniya Antey, Zabaykal'ye [Tectonophysics of Hydrothermal Ore Formation: an Example of the Antei Mo-U Deposit, Transbaikalia]. Geologiya rudnykh mestorozhdeniy - Geology of Ore Deposits, 2015, vol. 57, no. 4, pp. 327-350.

11. Petrov V.A., Poluektov V.V., Hammer J., Schukin S. I. Fault-related barriers for uranium transport. In: Uranium Mining and Hydrogeology. B. J. Merkel, A. Hasche-Berger (edit.). Springer-Verlag Berlin Heidelberg, 2008. Pp. 779-789.

12. Jobmann M., Flügge J., Gazul R., Hammer J., Herold P., Krone J., Kuate Simo E., Kühnlenz T., Laggiard E., Lommerzheim A., Meleshyn A., Müller C., Rübel A., Wolf J., Zhao H. Investigation on long-term safety aspects of a radioactive waste repository in a diagenetic clay formation. Final Report, Peine, DBE TECHNOLOGY GmbH, 2017.

13. Petrov V. A., Poluektov V. V., Hammer J. R., Tsulauf G. Issledovaniye mineral'nykh i deformatsionnykh preobrazovaniy gornykh porod Nizhnekanskogo massiva $\mathrm{v}$ tselyakh opredeleniya ikh uderzhivayushchey sposobnosti pri geologicheskom zakhoronenii i izolyatsii radioaktivnykh otkhodov [Study of mineral and deformation rock transformations in the Nizhnekanskiy massif aimed at identifying their retention capacity during geological disposal and isolation of radioactive waste]. Gornyi Zhurnal Mining Journal, 2015, no. 10, pp. 67-74.

14. Kamnev E. N., Karamushka V. P., Seleznev A. V., Morozov V. N., Hiller A. Ekologicheskiye problemy i ikh resheniye pri zakrytii uranovykh proizvodstv (na primere Rossii, SNG i Germanii) [Ecology of Uranium Mine Closure: Problems and Solutions (In Terms of Russia, CIS Countries and Germany]. Gornyy informatsionno-analiticheskiy byulleten' - Mining information and analytical bulletin, 2020, no. 5, pp. 26-39.

\section{Information about the authors}

Petrov Vladislav Alexandrovich, Corresponding Member of RAS, Doctor of Science, Professor, Director, Federal State Budgetary Institution of Science Institute of Geology of Ore Deposits, Petrography, Mineralogy and Geochemistry of the Russian Academy of Sciences (35, Staromonetnyi lane, Moscow, 119017, Russia), e-mail:vlad243@igem.ru.

Krone Jürgen, Ph. D., Senior consultant, BGE TECHNOLOGY GmbH (55, Eschenstrasse, Peine, D-3224, Germany), e-mail: krone.radeberg@freenet.de.

Kamnev Evgeniy Nikolaevich, RAEN Correspondent, Doctor of Geological at Mineral Sciences, Professor, Scientific Secretary, JSC Leading Design and Survey and Research Institute of Industrial Technology (33, Kashir Highway, Moscow, 115409, Russia), e-mail: Kamnev.E.N@vnipipt.ru.

Timayer Tatiana, Research Fellow, Curator of the German Ministry of Economy Russian-German cooperation on the burial of RAO, Federal Office for Geosciences and Natural Resources (BGR) (2, Stilleweg, Hannover, 30655, Germany), e-mail: tatjana.thiemeyer@t-online.de.

\section{Bibiliographic description}

Petrov V. A., Krone Jü., Kamnev E. N., Timayer T. Two-Decade Retrospective of German-Russian Cooperation in the Field of Safe Radioactive Waste Management. Radioactive Waste, 2021, no. 3 (16), pp. $72-79$. DOI: 10.25283/2587-9707-2021-3-72-79. (In Russian). 